\title{
European Integration Process: Where is Albania?
}

\author{
Merita Boka \\ PhD candidate in Financial Markets and Intermediaries, \\ Department of Management, University of Bologna, Italy \\ meritaboka@gmail.com, Cell.+355684099214
}

\section{Giuseppe Torluccio}

\begin{abstract}
Associate Professor of Banking \& Finance, Department of Management, University of Bologna, Italy Center for Research in Banking and Finance (CEFIN) - University of Modena and Reggio Emilia, Italy giuseppe.torluccio@unibo.it
\end{abstract}

\section{Doi:10.5901/ajis.2013.v2n9p44}

\section{Abstract}

The European integration process has, for more than two decades, represented a vital issue for Albania. This process has been evolving gradually and Albania is currently working towards receiving 'candidate country' status, subject to the fulfillment of key measures identified in the 2012 Albania Progress Report. This latest assessment is being carried out primarily according to the Copenhagen criteria: economic, political and acquis communautaire, those important for EU membership. Upon fulfillment and granting of candidate status, the next steps would be EMU and introduction of the euro. This is related to the Maastricht criteria fulfillment (convergence criteria) and would entail the following: price stability, exchange rate stability, fiscal criteria and long-term interest rate criteria. The main purpose of this paper is to consider how Albanian macroeconomic indicators comply with Maastricht criteria, and also to assess whether these indicators are methodologically harmonized and thus comparable to those of EU members. The paper also indicates the areas where progress is still needed in order to attain a favorable starting position for ERM II participation (after joining the EU).

Keywords: Albania, EU, convergence criteria, inflation criteria, ERM II

\section{Introduction}

The European integration process has, for more than two decades, represented a vital issue for Albania. This process has been evolving gradually and Albania is currently working towards receiving 'candidate country' status. This status is subject to the fulfillment of twelve key measures as identified by the 2012 Albanian Progress Report, which assesses the fulfillment based on the Copenhagen criteria, namely economic, political and acquis communautaire, all of which are crucial for European Union (EU) membership. Upon fulfillment and granting of candidate status, the next steps would be Economic and Monetary Union, and introduction of the euro. This is related to the Maastricht criteria fulfillment (convergence criteria), and would entail price stability, exchange rate stability, fiscal criteria and long-term interest rate criteria. It should be noted, however, that a unilateral introduction of the common currency would not suffice: the euro can be introduced only in agreement with EU member countries and only after the EU accession. Such agreement requires a two-year ERM II successful participation and the convergence criteria fulfillment. Given the dynamics and national aspirations, compliance of Albanian macroeconomic indicators with the Maastricht criteria gains significant research importance. Equally important is the matter of comparability: assessing whether these indicators are methodologically harmonized and thus comparable to those of the EU member states. Building on these two main aspects, this research paper will first assess the degree of Maastricht criteria fulfillment and progress conducted in achieving the preconditions for adoption of the euro. Following this, the paper will highlight the areas of intervention necessary on a macroeconomic and methodological level in order to ensure the comparability of domestic indicators with those of the EU. This study will be structured in four main parts. The first part provides a detailed description of the Copenhagen criteria and the Maastricht criteria, including a methodological harmonization analysis for each criterion; the second part of the paper focuses on the EU integration process of the Republic of Albania, highlighting the most important moments in EU-Albania relations. In the third part, the Maastricht criteria are analyzed in relation to the macroeconomic convergence of Albania 
with the EU. Finally, to conclude, the fourth part offers a summary of what has been achieved until now, and provides a number of recommendations on issues to consider for the future.

\section{Two Groups of Criteria: Copenhagen and Maastricht Criteria}

In the European integration process there are two important factors to consider: (i) criteria that a potential new member must fulfill in order to become a member country of the European Union (EU), and (ii) criteria that the member country must fulfill in order to adopt the euro as the national currency, or criteria to obtain full membership of the Economic and Monetary Union (EMU).

\subsection{Copenhagen Criteria}

After the fall of the Berlin Wall, Central and Eastern European countries showed their interest in joining the European Union. The European Council meeting in Copenhagen in June 1993 made an important decision, concluding that the "associated countries in Central and Eastern Europe that so desire shall become members of the European Union. Accession will take place as soon as an associated country is able to assume the obligations of membership by satisfying the economic and political conditions required". The Copenhagen criteria (economic, legal and political) were joined by the Madrid criteria, based on which the candidate country must create the conditions for its integration through the adjustments of its administrative structures. According to the Copenhagen criteria, qualification for membership includes:

- Stability of institutions, guaranteeing democracy, the rule of law, human rights and the respect for and protection of minorities;

- Existence of a functioning market economy as well as the capacity to cope with competitive pressures and market forces within the Union;

- Ability to take on the obligations of membership, including adherence to the aims of political, economic and monetary union.

\subsection{Maastricht Criteria}

In 1957, the Treaty of Rome established the European Economic Community (EEC) and the Treaty establishing the European Atomic Energy Community (EURATOM). Little of the Treaty concerned money, since the Bretton Woods System (which included Europe, North America and Japan) provided the international framework for currency stability. After the first signs of currency instability threatening international markets (German mark revaluation and French franc devaluation) economic and monetary union became an impetus goal at The Hague Summit in 1969. The Werner Report ${ }^{1}$ of 1970 represents the first official step towards the EMU proposing a three-step strategy within 10 years. This included stabilization and narrowing of the fluctuation margins between currencies of the member states, complete freedom of capital movements, and an irrevocable fixing of the exchange rates between the participating national currencies (Faulend, Loncarek, Curavic, \& Sabic, 2005). In 1979, a European Monetary System was built on the concept of a stable but adjustable exchange rate defined in relation to the newly-created European Currency Unit (ECU). An exchange rate mechanism (ERM) was created which allowed fluctuations around central rates. Formally, the introduction of EMU dates to 1988, with the Delors Report which proposed the concrete stages of EMU. In order to achieve EMU, several amendments to the Treaty were necessary. This led to the Treaty on European Union, formally adopted by the Heads of State and Government at the Maastricht European Council in December 1991. The Treaty of Maastricht provided three stages for EMU: Stage 1 (from 1 July 1990 to 31 December 1993) - free movement of capital between member states; Stage 2 (from 1 January 1994 to 31 December 1998) - economic policies co-ordination and stronger central bank cooperation; Stage 3 (underway since 1 January 1999) - gradual introduction of the euro ${ }^{2}$ as the single European currency for the member states, and implementation of the common monetary policy by the European Central Bank. Participation

\footnotetext{
${ }^{1}$ The Werner Report (1970) took for granted fixed exchange rates to the US dollar. After the US dollar effectively floated, efforts to tie communities' currencies more closely resulted in the "snake in the tunnel" mechanism for managing fluctuations of member currencies (the snake) inside narrow limits against the US dollar (the tunnel).

${ }^{2}$ The 1995 Madrid European Council agreed on the name for the new currency - the euro - and set out the scenario for the transition to the single currency that would start on 1 January 1999.
} 
in the third stage of EMU is subject to the fulfillment of the economic and legal convergence criteria laid down by the Treaty of Maastricht.

Price stability represents an important objective for most of the central banks, not only in the EU. Low and stable inflation is the main contribution that a central bank can make for the economy, an assessment generally accepted in literature, since it spurs economic activity and improves living standards (Feldstein, 1997; Akerlof, Dickens, \& Perry, 1996). This criterion was firstly established in the early 1990s in order to align high-inflation countries, such as Italy and UK, with low-inflation countries, such as Germany and the Netherlands, prior to the introduction of the euro. The first indent of Article 140(1) of the Treaty requires "the achievement of a high degree of price stability; this will be apparent from a rate of inflation which is close to that of, at most, the three best performing ${ }^{3}$ Member States in terms of price stability". Article 1 of the Protocol on the convergence criteria further states that "the criterion on price stability referred to in the first indent of Article 140(1) of the Treaty on the Functioning of the European Union shall mean that a Member State has a price performance that is sustainable and an average rate of inflation, observed over a period of one year before the examination, that does not exceed by more than $1 \frac{1}{2}$ percentage points that of, at most, the three best performing Member States in terms of price stability. Inflation shall be measured by means of the consumer price index on a comparable basis taking into account differences in national definitions". The average inflation rate is measured by the percentage change in the unweighted arithmetic average of the last 12 months' indices relative to the unweighted arithmetic average of the 12 monthly indices of the previous period, rounded to one decimal place. Considering an average value of the three best performing states (opposed to a fixed value) allows consideration of the effects on inflation rates across member states of common shocks. According to the Treaty, the concept of 'best performer state' is not clearly defined. In the 2004 Convergence Report, Lithuania was not considered among the best performing states in terms of inflation since it marked a negative inflation rate due to internal circumstances. In 2010, due to economic and financial crises, several countries experienced negative inflation rates. In this case Ireland was excluded from the best performers since its inflation rate deviated by a wide margin from the members states' average inflation rate, mainly due to domestic economic downturn (Convergence Report, 2010). According to the protocol on the convergence criteria, the member state should not only have achieved price stability, but its performance in terms of price stability should be sustainable and maintainable after adoption of the euro. Furthermore, inflation developments in the country should be the result of factors affecting prices (such as costs, wages, productivity, administered prices, taxes, etc) rather than factors causing temporary price fluctuations (Brůha, Podpiera, \& Polák, 2007).

Participation in the Economic and Monetary Union leaves no room for intervention in terms of monetary policy and exchange rate policy in order to respond to internal or external macroeconomic shocks. In this condition, the fiscal policy remains the only tool under a country's control to implement and maintain the macroeconomic equilibrium. Given the importance of this policy tool, and given the current problems deriving from poor fiscal management (e.g. in Greece), public finance criteria have become crucial nowadays. Pursuing sound and sustainable fiscal policies has become the argument of the day, and debates on it are still taking place. The EU convergence criteria related to the government budgetary position are defined in the second indent of Article 140(1) of the Treaty, which requires "the sustainability of the government financial position; this will be apparent from having achieved a government budgetary position without a deficit that is excessive as determined in accordance with Article 126(6)". Article 2 of the Protocol on the convergence criteria states that Article 140(1) of the Treaty stipulates that this criterion shall mean that "at the time of the examination the Member State is not the subject of a Council decision under Article 126(6) of the said Treaty that an excessive deficit exists". To assess whether a member state has an excessive deficit two criteria for budgetary discipline are considered as set in Article 162(2): one on the fiscal deficit and the other on public debt. Concretely, as defined in the protocol on the excessive deficit procedure, the examination should be based on two criteria:

a) Whether the ratio of the planned or actual government deficit to GDP exceeds a reference value (specified in the Protocol as $3 \%$ of GDP), unless:

- either the ratio has declined substantially and continuously and reached a level that comes close to the reference value; or, alternatively,

- the excess over the reference value is only exceptional and temporary and the ratio remains close to the reference value;

${ }^{3}$ Countries experiencing deflation are not considered as failing to meet the price stability criterion (Lithuania ECB Convergence Report, 2004). Also, best performer will be considering even a state with a negative inflation rate. 
b) Whether the ratio of government debt to GDP exceeds a reference value (defined in the Protocol on the excessive deficit procedure as $60 \%$ of GDP), unless the ratio is sufficiently diminishing and approaching the reference value at a satisfactory pace.

The relationship between a government deficit at $3 \%$ of GDP and public debt at $60 \%$ does not seem clear at first sight. As shown in Szapáry \& Orbán (2004), and Faulend et al. (2005), for a country with 3\% to GDP government deficit and $5 \%$ to GDP nominal growth rate, in the long run the public debt will stabilize at the level of $60 \%$ of GDP. It is interesting to note that at the time the Maastricht criteria were designed, the average public debt to GDP of the member states was approximately $60 \%$, and the potential growth rate was estimated at $5 \%$. Nowdays, the discussion on the public finances criteria is still open since economic conditions have changed over time. In fact, older member states have lower potential economic growth rates, and new member states and future potential member states actually have higher potential economic growth rates. The latter must simultaneusly pursue low budget deficits (3\% of GDP), raising questions on the long-term $60 \%$ of GDP debt sustainability (Szapáry \& Orbán, 2004). New member states and future member states with higher economic growth rates, in order to converge to "old member" standards, need to borrow more, and thus these criteria may sound somewhat inflexible.

Participation in EMU, like any other monetary union, entails technicalities such as the irrevocable fixing of member countries' exchange rates and elimination of cross-country exchange rates between member states. Far from being a technicality, its long-term stability concerns the attained nominal and real convergence level ${ }^{4}$, and the commitment and effort of the member state in adjusting economic policies into harmonization with those of the EU. If this feature is left unobserved, the consequences for that economy might be very harmful, hindering economic growth and causing a decline into economic recession. Nominal convergence (Maastricht criteria fulfillment) represents a precondition for the adoption of the euro, while real convergence does not. Although not required, the catching-up process represents an important step towards EMU facilitating the adherence to the Maastricht criteria (De Grauwe \& Schnabl, 2004). In order to avoid exchange rate manipulations and an unfair competitive position, nominal exchange rate convergence is required under the Maastricht criteria. The third indent of Article 140(1) of the Treaty requires "the observance of the normal fluctuation margins provided for by the exchange-rate mechanism of the European Monetary System, for at least two years, without devaluing against the euro". Also, Article 3 of the Protocol on the convergence criteria referred to in Article 140(1) of the Treaty stipulates: "The criterion on participation in the exchange-rate mechanism of the European Monetary System referred to in the third indent of Article 140(1) of the said Treaty shall mean that a Member State has respected the normal fluctuation margins provided for by the exchange-rate mechanism of the European Monetary System without severe tensions for at least the last two years before the examination. In particular, the Member State shall not have devalued its currency's bilateral central rate against the euro on its own initiative for the same period." After accession to the EU, membership to the ERM II can take place at any time and is voluntary for member states outside the euro zone. Also, an entering country, the euro area countries, and the ECB must agree on the central rate ${ }^{5}$ and fluctuating band ${ }^{6}$ around it. In this context relevant attention is paid to the determination of the reference value of the exchange rate. This is not coincident with the conversion rate (the rate at which the national currency will be converted to the euro). These represent two different decisions at two different moments in time.

The alignment of long-term interest rates between member countries represents the fourth economic convergence criterion. There is a pragmatic reason behind this interest rate criterion: prevention of capital gains on bonds issued by countries that paid a high premium due to exchange rate risks (De Grauwe, 2012). If it is known that the exchange rate will be fixed, investors will sell low premium bonds lowering their price and increasing interest rates on them) and will buy high premium bonds (increasing their price and decreasing interest paid on them). In countries with initial low interest rates, interest rates will grow and holders of bonds will experience a capital loss; in a country with initial high interest rates, interest rates will fall and bond holders will have a capital gain. In order to avoid these unfair capital gains and losses the fourth indent of Article 140(1) of the Treaty requires "the durability of convergence achieved by the Member State with a derogation and of its participation in the exchange-rate mechanism being reflected in the long-term interestrate levels". To monitor the fulfillment of this criterion, article 4 of the Protocol on the convergence criteria referred to in

\footnotetext{
${ }^{4}$ Nominal convergence refers to Maastricht criteria fulfillment, and real convergence (or catching-up process) refers to the attainment of other member states' average income per capita, implementation of necessary structural reforms and the creation of the institutional structures close to those of EU.

${ }^{5}$ This will be used as a reference value to observe possible exchange rate fluctuations.

${ }^{6}$ The standard fluctuating band is $+/-15 \%$, and a country may agree to adopt a narrower fluctuation band such as $+/-2.5 \%$, on the request of the country and subject to multilateral agreement.
} 
Article 140(1) of the Treaty stipulates: "The criterion on the convergence of interest rates referred to in the fourth indent of Article 140(1) of the said Treaty shall mean that, observed over a period of one year before the examination, a Member State has had an average nominal long-term interest rate that does not exceed by more than two percentage points that of, at most, the three best performing Member States in terms of price stability. Interest rates shall be measured on the basis of long-term (10 years) government bonds or comparable securities, taking into account differences in national definitions". Given differences in national bonds and/or securities, it is important to choose those bond yields (as a reference for long-term interest rate) that fulfill the following criteria (ECB, 2003): (a) bonds should be issued by the central government, given that these represent the most secure type of bonds and their prices are less affected by risk considerations; (b) maturity as close as possible to 10 years residual maturity; (c) sufficiently liquid bonds determining the choice between benchmark of sample approaches, depending on national market conditions ${ }^{7}$; (d) coupon effects: no direct adjustment ${ }^{8}$; (e) gross of tax; (f) yield formula: yield to maturity formula based on ISMA formula $6.3^{9}$; $(\mathrm{g})$ in the case of more than one bond, the simple average yield should be used to produce a representative rate. What happens if a country does not have long-term government bonds or those present have no benchmark characteristics? If this is the case, it is possible to consider comparable financial instruments, as in the case of Estonia ${ }^{10}$ and Luxembourg ${ }^{11}$ : since they do not have government debt, there are no bonds available (Convergence Report, 2010).

\section{Macroeconomic Convergence: Where is Albania?}

Although the fulfillment of the Maastricht criteria is not relevant to EU membership, understanding the level of their fulfillment (or otherwise) is useful in order to orient the necessary steps to cope with them by the time the country joins the EU. Addressing the problems and trying to find a solution would enable the country to join the ERM II and increase the probability of adopting the euro as the national currency. According to Faulend et al. (2005), the speedy introduction of the euro has several positive aspects, such as: (a) euro adoption would eliminate the need to hold surplus international reserves, (b) monetary policy could produce countercyclical effects, (c) there would be disappearance between internal and external debt so that the government could access funds transparently and under the same conditions lower government financing costs, (d) price comparisons would be easier, thus boosting international trade and lowering conversion costs, and (e) there would be elimination of currency risks from all balance sheets ${ }^{12}$. Also, Fagan \& Gaspar (2008), using a two countries model, showed that the creation of monetary union leads to an increase in welfare for all generations.

\subsection{Price Stability Criteria}

Since the first seeds of calculation in 1958-1960, and then from December 1993, the average annual inflation rate in Albania has been calculated using changes in the Consumer Price Index (CPI). After regime changes post 1990, the inflation rate exploded to three-digit figures, especially in the first six months of 1993 , following a spiral path over the next years. In the first years of transition a progressive reduction of the inflation rate was observed, from $85.0 \%$ in 1993 to $22.6 \%$ in 1994 , and reached a single-digit figure of $7.8 \%$ in 1995 . The relatively low inflation-rate period was short since the following year it almost tripled, and at the end of 1997 the annual inflation rate reached $42.0 \%$ due to the pyramid schemes' collapse during the spring of 1997. From the financial point of view, this collapse was considered the most

\footnotetext{
${ }^{7}$ Sample approach: yields calculated using this approach are more stable over time and substitution effects of the basket are dampened, avoiding maturity drifting effects. For small markets with limited financial instruments, this is not the most appropriate approach since the range of liquidity can be very different. Using the benchmark approach a single very liquid bond is considered, but in small markets such bonds are not issued regularly and frequently.

${ }^{8}$ Theoretically, there is a positive relationship between coupon and bond prices and an inverse relationship between bond price and yields. There is no suitable way to adjust for coupon effects since the extent to which changes in bond prices affect the yield is weighted by the coupon value. If coupons differ significantly across countries, yields are not comparable and nor are their changes.

9 International Securities Market Association formula: $P=\sum_{i=1}^{n} C F i * V^{L i}$, which is the same across member states of the EU.

${ }^{10}$ For Estonia, the indicator for long-term interest rates is considered as the bank's interest rate applied to long-term loans (in national currency) to households and businesses (non-financial corporations) over 5 years' maturity.

${ }^{11}$ For Luxemburg, the indicator is based on a basket of securities (issued by a bank with solid rating) with common residual maturity of 10 years.

12 There will still be currency risks for non-euro deposits and loans (those in US dollars, for example).
} 
difficult moment to be managed by the monetary authority in Albania (Bank of Albania, 1999). Its consequences affected the country's economic development for a long period. The following year was a period of recovery characterized by efforts by the central bank and international institutions (such as the IMF) to bring the inflation rate under control. In December 1998, the annual inflation rate was measured at $8.7 \%$. At the same time, when the consequences of the pyramid schemes collapse became evident in the Albanian economy, another shock - this time an external one, the Kosovo crisis - hit the Albanian economy. Kolasi, Çeliku, \& Hashorva (2001) empirically showed that political events, such as elections, do not significantly affect inflation rates. On the other hand, high-tension periods, such as the 1997 financial crisis and the 1999 Kosovo crisis, did significantly affect the inflation rate. In 1997 the crisis caused high inflation rates, and the Kosovo crisis resulted in lower inflation rates (Kolasi et a., 2001). The latter development may have been caused by the high inflow of goods in terms of aid, which in turn lowered internal prices. Also the exchange rate may have contributed to prices moving in the same direction. The years 1999-2000 were characterized in general by negative annual inflation rates determining a slightly deflationary period mainly due to the base effect of the previous year. These levels of inflation were too low, and unexplainable under liberal economic policies, with economic growth rates as high as 7.3\% year on year (Bank of Albania, 2000). This period did not last too long. In fact, at the end of 2000 the central bank declared publicly that the economy was ahead of intensified inflationary pressures. Although under constant and careful monitoring by the Bank of Albania, the annual inflation rate in July 2001 jumped to $5.6 \%$ and in February 2002 it jumped to $7.7 \%$. The high inflation rates registered in the period under consideration were the result of a series of factors such as an electricity energy crisis, political uncertainty due to the June 2001 elections, higher administered prices of energy and water, slower international economic growth, turmoil in Macedonia, introduction of the euro at the beginning of 2002, and the financial crisis in Turkey. An important event for the national CPI was the introduction of a new basket (a structural change) at the beginning of 2002 and the calculation of a new CPI. From 2003, inflation developments in Albania have been under the pressure of domestic and international macroeconomic developments. We can observe that the annual inflation rate has stabilized within the Bank of Albania tolerance band, sometimes overshooting or undershooting the main target of $3 \%{ }^{13}$. This has been mainly due to the influence of certain common factors, such as switching to indirect instruments of monetary policy from 2002, a consolidated fiscal policy, a very active, prudent and strong commitment of the Bank of Albania in pursuing its monetary policy primary objective, and from 2011 the very low influence of the administrated prices. Although this can be considered a period of stable and low inflation for a country like Albania where there are still structural reforms ongoing, the informal economy is estimated to still be high, with the privatization process not yet concluded, and subject to external shocks from international trade channels. For the period 2007-2011 the average inflation rate was $3.1 \%$, close to the mid-term objective of the Bank of Albania. Turmoil in the financial markets started in 2008, which coupled with the sovereign debt crisis in some EU countries - Albania main trading partners intensified uncertainties in the real sector of the economy. Monetary policy was forward-looking and timely decisions were very important in order to attain and maintain price stability in this period (Çeliku, 2011).

We return to our main question: does Albania meet the price stability criteria?

First of all, we should consider whether the CPI produced by the Albanian Institute of Statistics is comparable with the Harmonized CPI calculated by Eurostat. In view of the publicly available data and information, and the methodology used to calculate the $\mathrm{CPI}$ in the country, it is impossible to make relevant comparisons with EU data mainly due to mismatches on treating special aspects. It has been publicly declared by INSTAT that the actual CPI is calculated as close as possible to that of Eurostat ${ }^{14}$, and it is commonly used to make international comparisons. If we assume that data on the Albanian CPI corresponds to that of HCPI (if it was calculated), if it was comparable with EU data, Albania would already fulfill the inflation criteria if the assessment took place on 01 January 2013 (see Annex A).

Inflation rate in Albania and reference values for EU.

${ }^{13}$ From the beginning of 2006 , the Bank of Albania adopted a point objective of $3 \%$ for the annual inflation rate instead of the previous interval tolerance band of $2 \%-4 \%$. For more information see Monetary Policy Document 2009-2011.

${ }^{14} \mathrm{COICOP}$ methodology and 12 categories matching those of Eurostat. 


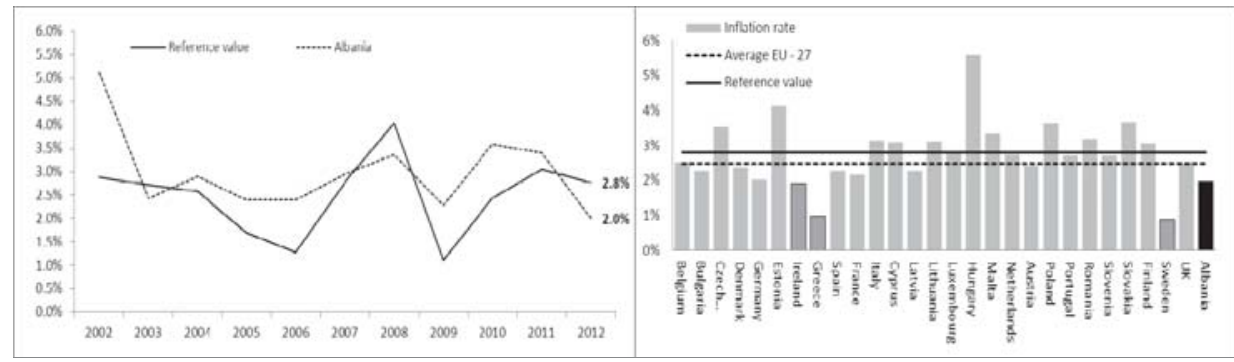

Source: Albanian National Institute of Statistics (INSTAT).

It would be very easy to conclude that Albania fulfills the price stability criteria as specified by the Maastricht Treaty and following protocols. However, we should bear in mind that the convergence of national average prices to EU average prices is a long-term process not only in transition countries but even in established member countries. For the period under consideration we can observe that Hungary, Estonia and Czech Republic do not converge in terms of average prices to the reference value, and they remain far from the average inflation rate observed for 2012. For the evaluation period, Albania's inflation rate lies close to the best-performing countries and close to the average value of the inflation rate for the EU-27 for 2012. To highlight this, the Bank of Albania "is granted the exclusive right to independently implement the monetary policy" 15 ", it has as its main task "to independently formulate, adopt and implement the monetary policy of the Republic of Albania, consistent with its main objective ${ }^{16 "}$, and the primary objective of the Bank of Albania is to "achieve and maintain the price stability ${ }^{17 "}$ ". In quantitative terms, the Bank of Albania defines price stability as keeping the CPI inflation rate at the level of $3 \%$, with a tolerance bank of $+/-1$ percentage point around its point target. From this point of view, the primary objective pursued by the central bank in Albania is higher than that of the European Central Bank. The divergence between the two targeted inflation rates is related to certain country-specific characteristics. As confirmed by the Bank of Albania ${ }^{18}$, the definition of the target for inflation reflects the level of development of the country as a small, open, and emerging economy. In this condition, it is characterized by high relative price volatility towards finding stable structural balances of the market economy. Also, it is considered that the target of $3 \%$ supports the EU integration process and assures a reasonable time span for real and nominal convergence of the Albanian economy with that of the EU. For all the above-mentioned reasons it is expected that Albania could have fewer "problems" in the adjustment process to the EU in terms of prices. Also the presence of a number of mechanisms of an administrative nature, such as a decrease in indirect taxes (excise duties on fuels) and restrictions or deceleration in administrated prices (electrical energy, water, health services, education services), can influence the inflation rate if necessary. It seems that the current price stability level pursued is safe from threats, but we should still be very careful in making final conclusions. We are not immune to international developments, and it is almost impossible to account for all the external shocks that may occur and could affect the domestic inflation rate. Also, another very important point consists in the fact that the price stability criteria represent a moving target; the reference value is not fixed as in the case of fiscal criteria. So, maintaining price stability requires strong efforts and commitment of the central bank, and a key to success may be the good co-ordination of monetary policy with fiscal policy.

\subsection{Fiscal Criteria}

With regard to the fiscal criteria, these consist of two sub-items: the overall government budget deficit/surplus and public debt. With regard to the government budget deficit we need first to consider the methodological aspects. In Albania, the compilation methodology underlying the data for the consolidated budget is broadly consistent with the analytical framework set out in the IMF's "Manual on Government Finance Statistics, 1986"19. Future plans concern the adoption of

\footnotetext{
${ }^{15}$ Article 161 of the Constitution of the Republic of Albania.

${ }^{16}$ Article 3, paragraph 4a of the Law No.8269, dated 23 December 1997, "On the Bank of Albania".

${ }^{17}$ Article 3, paragraph 1 of the Law No.8269, dated 23 December 1997, "On the Bank of Albania".

${ }^{18}$ Monetary policy document for the period $2012-2014$.

${ }^{19}$ Source: http://www.dsbb.imf.org/Pages/GDDS/DQAFViewPage.aspx?ctycode=ALB\&catcode=CGO00\&Type=CF
} 
the methodology of the IMF's "Government Finance Statistics Manual, 2001" (GFSM 2001). In order to monitor fiscal criteria convergence, calculations must be made using the Eurostat ESA 95 methodology. Nowadays, EU-27 member states have almost completed the harmonization of their methodologies to ESA 95, and data are reported according to ESA 95. Keeping in mind these methodological differences in calculating the government budget in Albania and EU countries, we can see whether these criteria are fulfilled or not. As regards fiscal data from 2001, a constant decline in the government budget deficit can be noticed until 2006. The expansionary fiscal policy over 2008 was reflected in higher public expenditure and consequently a higher budget deficit, reaching $-5.5 \%$ of GDP. The widening of the budget deficit over 2008-2009 was mainly due to higher public investments, especially those going towards the Durrës-Kukës highway. Observing the public debt to GDP threshold (below 60\% of GDP), and maintaining low budget deficits, were the two most important objectives set out in the Fiscal and Macroeconomic Framework for 2010-2012. This was mainly due to the deterioration of the fiscal position in 2009. In contrast to the previous two years of fiscal stimulus, fiscal policy during 2010 was oriented towards fiscal consolidation through lower expenditure and higher revenues, leading to an almost 53\% reduction of the government budget deficit for 2010. With a view to maintaining public finance sustainability, even during 2011 it was necessary to pursue a prudent fiscal policy. So, for 2011 the overall fiscal policy could be considered slightly stimulating. When we consider the reference value of the EU for the budget deficit of $3.0 \%$, at first sight one can conclude that Albania does not fulfill this criterion. During 2012, the preliminary data show that the budget deficit amounted to 3.3\% of GDP, $0.3 \%$ higher than the EU reference value. An interesting fact is that, in the current situation, data for 2011 show that the budget deficit to GDP ratio for Albania remains very close to those of the new EU members, and closer to the EU reference value than some established members of the EU.

Government budget balance in Albania (\% of GDP) and public debt (\% on GDP).

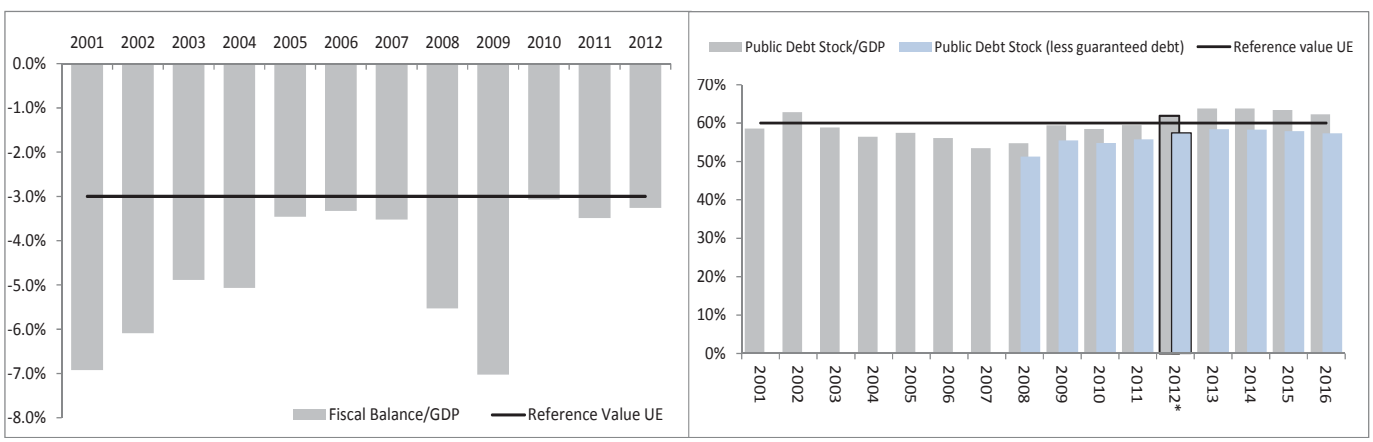

Source: Ministry of Finance, Instat.

Note: For 2012 preliminary data from the Ministry of Finance.

With regard to the fiscal criteria, the Maastricht Treaty goes beyond the fiscal deficit and also considers the public debt criteria. As mentioned above, the consolidated government debt in Albania is calculated according to the IMF's "Manual on Government Finance Statistics, 1986." From the methodological point of view, the data on the public debt cover the internationally recognized definitions of central, local and general government. The general government in Albania consists of two levels, central and local government. According to the Organic Budget Law ${ }^{20}$, government guarantees are included. These are not in line with GFS 2001 and ESA 95 methodology. Given the current methodological differences in government debt statistics we can say that they are not entirely adjusted to the EU requirements. If we consider the data on the public debt in Albania, a progressive reduction can be noticed from 2002. The overall public debt registered its lowest level in 2007, accounting for about $53.4 \%$ in terms of nominal GDP. In 2008, mainly due to capital expenditure financing needs, the public debt stock increased, reaching $54.7 \%$ of GDP in 2008 and $59.4 \%$ of GDP in 2009. Given the

\footnotetext{
${ }^{20}$ Units of the central government are: President, the Parliament, the Council of Ministers, 14 ministries, 8 non-ministerial departments, and various central institutions; Social Security Institute; Health Care Insurance Institute. The local governments cover 36 districts and 43 municipalities (including Tirana, which is both a district and municipality). There are no extra-budgetary operations at either central or local government level. Source: http://www.dsbb.imf.org/Pages/GDDS/DQAFViewPage.aspx?ctycode=ALB\&catcode=CGO00\&Type=CF 20 Law No. 8379, dated 29.07.1998 on the "Preparation and execution of the state budget of the Republic of Albania".
} 
2008 financial crises and the debt crisis in Greece, and as part of the National Strategy for Development and Integration, a more prudent and better administration of the public debt strategy was adopted ${ }^{21}$. This strategy comprised two main elements: domestic debt maturity extension and, from the technical point of view, the improvement of the securities market infrastructure (Bank of Albania, 2008). For better comparability, Albanian government debt without guarantees issued is calculated, too, although methodological differences still persist. Data show that for several years, the Albanian government debt stood below the UE threshold of $60 \%$ of GDP, fulfilling this fiscal criterion even though by a small margin. Far from the point assessments, which currently are not coherent since methodological differences are present, it is important to notice that the public debt in Albania has been relatively close to the $60 \%$ threshold. From 2010, the public debt in terms of GDP increased slightly year by year, and is predicted to be over the EU threshold for the next 4 years. Reasoning is different if we consider the public debt to GDP less guarantees. For the period 2008-2011, these stayed below the $60 \%$ threshold, and for 2012-2016 are predicted to increase but without passing the $60 \%$ threshold.

\subsection{Exchange Rate Stability Criterion}

The exchange rate stability criterion requires successful participation in the ERM II, a multilateral agreement, for at least two years after the EU accession of the country. So, at this time it is not particularly important to discuss whether Albania fulfills the exchange rate criteria. In order to make assessments on this criterion it is necessary for all member states to agree on a central rate of the Albanian currency's lek against the euro. Looking at the fluctuations in the exchange rate of the lek against the central rate enables an assessment of whether the country has participated successfully in the ERM II or not. To get an idea on the exchange rate of the lek against the euro in Albania we can simplify things by considering the exchange rate fluctuations over the last decade. Of course, whether the exchange rate shows relative stability or not, we cannot conclude that Albania formally fulfills the exchange rate criteria. Another thing to bear in mind is that prior to EU accession the capital account should be fully liberalized. Although in fact capital transactions have been liberalized to a large extent, the catching-up process (real convergence) 22 (Faulend et al., 2005) may bring some uncertainty in maintaining the exchange rate fluctuations within the narrower interval (+/- 2.25\%). In actual fact, the Bank of Albania implements a free-floating exchange rate regime, where the value of the Albanian lek is freely determined in the foreign exchange market by the interaction of supply and demand ${ }^{23}$. The free floating regime allows the Bank of Albania monetary policy to have the maximum flexibility in achieving its inflation target, and enables the free movement of goods and capital. As stated in the Monetary Policy Document for 2012-2014, the Bank of Albania reserves the right to intervene in the foreign exchange market in order to increase the level of foreign reserves and contribute to the stabilization and development of the domestic financial markets. All interventions will be made transparent to the public, will be in accordance with internal relevant regulations, and will not prejudice the achievement of the primary objective of the central bank. After a continuous depreciation of the lek until 2003, in 2004 the national currency reinforced its position against the euro, mainly due to long-term domestic factors (Bank of Albania, 2004), such as a constant consolidation of economic stability which enhanced confidence in the Albanian financial system and in lek monetary assets; the lek's real interest rates being higher than foreign currency interest rates and thus encouraging a high demand for the lek ${ }^{24}$; and consolidation of public finances and budget deficit which led to a low demand by the government for monetary assets. From 2004 to 2008 a progressive appreciation of the lek is noticed, reflecting the domestic macroeconomic stability, the deepening of the interest rates difference, and the comparable inflation rates with main partners (Bank of Albania, 2005, 2006, 2007). The global financial crises that involved international markets shook public confidence in the financial system and its instruments, raising market agent uncertainty and psychological effects. In the foreign exchange market, the lek depreciated against the euro, marking the highest depreciation since 2001. Ongoing effects of the euro-zone crisis brought a further depreciation in the national currency through 2010 and 2011 (Bank of Albania 2010, 2012). Apart from seasonal factors, the lek's exchange rate against the euro seems to have found a new equilibrium around the average value of 139 lek per euro. Overall, we can conclude that in average terms the euro/lek exchange rate has been relatively stable over the last decade. This is not enough, however, to enable us to assess whether Albania fulfills the exchange rate stability criteria since we do not yet have a central rate.

\footnotetext{
${ }^{21}$ Annual Report, 2008, Bank of Albania.

${ }^{22}$ Especially if primarily manifested in appreciation pressures rather than higher inflation rates.

${ }^{23}$ Monetary Policy Document for 2012 -2014, Bank of Albania.

${ }^{24}$ Even though Lek interest rates have been declining, the low inflation rates have maintained high real interest rates in Lek. 


\subsection{Long-Term Interest Rate Criterion}

In order to assess whether Albania meets the long-term interest rates criteria, first we need to consider the instruments issued by the government 25 , which include T-Bills ( 3 and 6 months' maturity with monthly frequency, 12 months' maturity with twice-a-month frequency); T-Notes (bonds - 2 years' maturity with once-a-month frequency, 3 and 5 years' maturity with three-monthly frequency, and 7 years' maturity with irregular frequency). In view of the methodological requirements, there are no 10-year residual maturity government bonds in the lek, so there is no interest rate to be considered as a benchmark rate (Amerini, 2004). Traditionally, the former practice of the government was to rely more on domestic funds using T-bills as an instrument, and only in the last few years have they introduced T-Notes. The 7-year maturity bond, the one with the longest maturity in Albania, does not have regular frequency ${ }^{26}$. The primitive secondary market is limited to a large extent to bond trading and issuance by the government. At the current stage there are no government bonds to fulfill the requirements for a benchmark interest rate. When there are no instruments fulfilling the requirements established by the Treaty, alternative comparable instruments can be considered, as in the case of Estonia, where the long-term interest rate on loans has been used as a benchmark rate (Faulend et al, 2005). In Albania, the greatest proportion of long-term loans is mainly in foreign currency ${ }^{27}$, often indexed to Euribor, as a result of the considerable rate of euroisation of the economy. It is doubtful whether these interest rates on long-term loans can be used as a suitable reference value. It is not possible to predict how the internal securities market will develop in Albania. It is possible that, until the day Albania joins the EU, securities markets will evolve and demand for longer maturity lek-denominated bonds will increase. Also, we cannot know if the Albanian government will issue a 10-year bond, but if the condition of liquidity is satisfied, even the 5-year bond can be used as an instrument to calculate the benchmark rate (as formerly used in the case of Greece). At the current stage, we cannot make an assessment regarding the compliance of interest rates with the Maastricht requirement.

\section{Conclusions}

In this paper we have attempted to present the current stage of the Copenhagen criteria compliance prior to EU accession, and the Maastricht convergence criteria for EMU. We have paid special attention to the Maastricht economic convergence criteria (price stability, exchange rate stability, long-term interest rates and fiscal criteria). These indicators for Albania are not methodologically harmonized with those of EU member countries, and thus are not fully comparable with them. Exception is made for $\mathrm{CPI}$, which is mostly in line with $\mathrm{HCPI}$ calculated by Eurostat methodology. If we assume that the Albanian CPI is sufficiently comparable with $\mathrm{HCPI}$ calculated by Eurostat, we can conclude that Albania fulfills the price stability criteria. The reference value is not fixed, so the assessment refers to a point in time. What is important to stress is that the monetary authority in Albania is strictly committed to attaining and maintaining price stability. Experience has shown that the Bank of Albania has been relatively successful in achieving its primary objective. With regard to fiscal criteria - overall government budget deficit and public debt - there is a weak methodological alignment to the international standards for fiscal accounts (Albania still uses GFS 1986 and EU member countries are aligned to ESA 95). Since there is no central rate, it is not possible to make an assessment related to the exchange rate stability criteria. Finally, regarding long-term interest rate criteria it is crucial to determine which interest rate can be used as the most suitable for comparisons. In fact, the high level of euroisation, primitive secondary market and lack of longterm financial instruments (bonds) make this task rather difficult. Given the above considerations, strong efforts should be directed towards methodological harmonization, determination of the central rate, and finding the appropriate financial instrument to use in order to calculate the benchmark interest rate. Given the current situation in European markets, fiscal consolidation should be considered as a primary objective, although the Albanian government has been committed to low budget deficit and under $60 \%$ public debt objectives. At the current stage of development, infrastructural investments are vital to the Albanian economic development, so the public debt will almost surely increase in the coming years. Not to be neglected is the attainment and maintenance of low positive inflation rates, given the structural changes still being undergone by the Albanian economy and the forthcoming real convergence to EU price levels. Also, as stated in Bulír \& Hurník (2006), the price stability criteria should not encourage the country to adopt short-term measures to reduce

\footnotetext{
${ }^{25}$ Source: Ministry of Finance, Albania.

${ }^{26}$ It was first issued on 07.12.2007 and re-issued on 18.06.2012.

${ }^{27}$ Foreign currency loans accounted for about $67.5 \%$ of the total loans in 2011 and $61.4 \%$ in 2012. 
inflation rather than structural reforms with longer-term benefits. With regard to the exchange rate stability, the experience of the former ERM/ERM II participants suggests that ERM II membership will be less stressful to candidate countries if the exchange rate band is underpinned by stability-oriented and credible domestic economic policies (Komárek, Čech, \& Horváth, 2003). In conclusion, now that the country has set as its long-term objective, since 1992, integration with Europe, efforts should not stop in fulfilling firstly the Copenhagen criteria, and then the Maastricht criteria. Continued and sustained efforts should be made to permanently meet these criteria and assure the competitiveness of the Albanian economy in European markets.

\section{Acknowledgements:}

This paper was realized with the financial support of the Excellence Fund Program, Ministry of Education and Science, Albania.

\section{References}

Akerlof, G. A., Dickens, W. T., \& Perry, G. L. (1996). The macroeconomics of low inflation. Brooking Papers on Economic Activity, p. 176.

Amerini, G. (2004). Long - term interest rates for acceding countries. Eurostat Statistics in Focus, Theme 2-21.

Bank of Albania. Annual Report 1999 - 2012. Bank of Albania.

Bank of Albania (2001). Annual Report 2000. Bank of Albania.

Bank of Albania (2012). Monetary policy documet for the period 2012 - 2014. Bank of Albania.

Bank of Albania (2010). Monetary policy documet for the period 2009 - 2011. Bank of Albania.

Buliř, A., \& Hurník:, J. (2006, August). The Maastricht inflation criterion: "saints" and "sinners". Czech National Bank.

Çeliku, E. (2011). Shocks to inflation in 2007 - 2011 in Annual Report 2011, Bank of Albania .

De Grauwe, P. (2012). Economics of Monetary Union. Oxford University Press, 9th edition.

De Grauwe, P., \& Schnabl, G. (2005). Nominal versus real convergence - EMU entry scenarios for the new member states. KYKLOS, Vol 58-2005-No. 4, 537 - 555.

European Central Bank. (2003, October). Bond markets and long term interest rates in European Union accession countries. European Central Bank.

European Commission. (2013).Convergence report 2012. Economic and Financial Affairs. European Commission.

European Commission. (2010).Convergence report 2010. Economic and Financial Affairs. European Commission.

European Commission. (2004). Convergence report 2004. Economic and Financial Affairs. European Commission.

Eurostat, (2004). Harmonized indices of consumer prices (HICPs): A short guide for users, available at http://epp.eurostat.ec.europa.eu/cache/ITY_OFFPUB/KS-BE-04-001/EN/KS-BE-04-001-EN.PDF

Eurostat, (2002). ESA 95 manual on government debt and deficit. Office for the Official Publications of the European Communities available at

http://epp.eurostat.ec.europa.eu/cache/ITY_SDDS/Annexes/naga_a_esms_an1.pdf

Eurostat, (2004). Long-term Interest Rates for Acceding Countries, Statistics in Focus - Theme 2-21/2004, available at http://europa.eu.int/comm/eurostat/

Fagan, G., \& Gaspar, V. (2008, December). Macroeconomic Adjustement to Monetary Union. Czech National Bank.

Faulend, M., Loncarek, D., Curavic, I., \& Sabic, A. (2005, July). EU criteria with special emphasis on the economic convergence criteria Where is Croatia? Croatian National Bank.

Feldstein, M. S. (1997). The costs and benefits of going from low inflation to price stablity. NBER Working Paper 5469.

Kolasi, G., Çeliku, E., \& Hashorva, G. (2001, Dhjetor). Tendenca e inflacionit në Shqipëri gjatë dekadës së kaluar: një vështrim empirik. Buletini Ekonomik V.4 No.4, Bank of Albania.

Komárek, L., Čech, Z., \& Horváth, R. (2003, December). ERM II Membership - the View of the Accession Countries. Czech National Bank.

Ministry of Finance. (2013). Macroeconomic and Fiscal Framework for 2014 -2016. Ministry of Finance of Albania.

Ministry of Finance. (2009). Macroeconomic and Fiscal Framework for 2010 - 2012. Ministry of Finance of Albania.

Ministry of Integration (2009). Stabilization and association agreement. Ministry of Integration, Albania.

Ministry of Integration (2012). Albania progress report 2012. Ministry of Integration, Albania.

Szapáry, G., \& Orbán, G. (2004, May). The stability and growth pact from the perspective of new member states. Magyar Nemzeti Bank.

\section{Legal resources}

Conclusions of the Presidency, European Council in Copenhagen, June 21 - 22, p. 13 available at http://ec.europa.eu/bulgaria/ documents/abc/72921_en.pdf 
Council Regulation (EC) No. 3605/93 of 22 November 1993 on the application of the Protocol on the excessive deficit procedure annexed to the Treaty establishing the European Community.

Protocol on the convergence criteria, Official Journal of the European Union. 2004, available at http://eurlex.europa.eu/LexUriServ/LexUriServ.do?uri=OJ:C:2004:310:0339:0340:EN:PDF

Resolution of the European Council on the establishment of an exchange rate mechanism in the third stage of economic and monetary union, Official Journal C 236, 2/8/1997.

Treaty on European Union (consolidated text), Official Journal C 325, 24/12/2002.

\section{Annex A}

Table A1. Best-performing EU countries at the end of December of each year.

\begin{tabular}{|c|c|c|c|c|c|c|c|}
\hline & & \multicolumn{3}{|c|}{ Best performing countries } & Average & $\begin{array}{c}\text { Reference value } \\
\text { (Average +1.5\%) }\end{array}$ & Albania \\
\hline \multirow{3}{*}{ EU 15 } & 2002 & Belgium & Germany & United Kingdom & $1.4 \%$ & $2.9 \%$ & $5.1 \%$ \\
\cline { 2 - 8 } & 2003 & Germany & Austria & Finland & $1.2 \%$ & $2.7 \%$ & $2.4 \%$ \\
\cline { 2 - 8 } & 2004 & Denmark & Sweden & United Kingdom & $1.1 \%$ & $2.6 \%$ & $2.9 \%$ \\
\hline \multirow{2}{*}{ EU 25 } & 2005 & Czech Republic & Denmark & Netherlands & $1.6 \%$ & $1.7 \%$ & $2.4 \%$ \\
\cline { 2 - 8 } & 2006 & Poland & Finland & Sweden & $1.3 \%$ & $1.3 \%$ & $2.4 \%$ \\
\hline \multirow{5}{*}{ EU 27 } & 2007 & Malta & Netherlands & Finland & $1.3 \%$ & $2.8 \%$ & $2.9 \%$ \\
\cline { 2 - 8 } & 2008 & Germany & Netherlands & Portugal & $2.5 \%$ & $4.0 \%$ & $3.4 \%$ \\
\cline { 2 - 8 } & 2009 & Ireland & Spain & Portugal & $-0.4 \%$ & $1.1 \%$ & $2.3 \%$ \\
\cline { 2 - 8 } & 2010 & Ireland & Latvia & Slovakia & $0.9 \%$ & $2.4 \%$ & $3.6 \%$ \\
\cline { 2 - 8 } & 2011 & Ireland & Slovenia & Sweden & $1.5 \%$ & $3.0 \%$ & $3.4 \%$ \\
\cline { 2 - 8 } & 2012 & Ireland & Greece & Sweden & $1.3 \%$ & $2.8 \%$ & $2.0 \%$ \\
\hline
\end{tabular}

Source: Albanian National Institute of Statistics and Eurostat.

For 2004: Finland inflation rate has been excluded from the calculation since it was too low compared to the average inflation rate of EU-15.

For 2005: Finland and Sweden inflation rate have been excluded from the calculation since it was too low compared to the average inflation rate of EU-25.

For 2009: Finland inflation rate has been excluded from the calculation since it was too low compared to the average inflation rate of EU-27 and related to internal economic problems.

For 2010: Finland inflation rate has been excluded from the calculation since it was too low compared to the average inflation rate of EU-27 and related to internal economic problems. Also Latvia inflation rate has been excluded since too low compared to the average inflation rate of EU-27. 